DOI: $10.15393 /$ j9.art.2019.5901

УДК 821.161.1.09“18”-31

Валентина Ивановна Габдуллина

(Барнаул, Российская Федерация)

vigv@mail.ru

\title{
Рукопись Ипподита Терентьева в романе Ф. М. Достоевского «Идиот»: жанр и нарративные стратегии
}

Аннотация. Рукопись Ипполита Терентьева «Мое необходимое объяснение», которая в тексте романа Ф. М. Достоевского «Идиот» называется то «статьей», то «тетрадкой», в литературоведении традиционно рассматривается как исповедь. Между тем жанровая и нарративная структура рукописи Ипполита неоднородна и многослойна. Сопряжение в тексте различных дискурсивных стратегий обоснования «последнего убеждения» идеологического самоубийцы с позиций логики сознания (тезис) и подсознания и «живой жизни» (антитезис) расширяет жанровые рамки исповедального слова. Идея о праве человека на самоубийство представлена в рукописи цепью логических умозаключений в нарративе, тяготеющем к философско-публицистическому дискурсу, убежденность и страстная эмоциональная форма которого отсылает к жанру проповеди. Логика подсознания умирающего юноши апеллирует к образам Апокалипсиса и небытия, проникающим в онейрический нарратив. Страх смерти и потеря веры воплощаются в дискурсивной стратегии экфрасиса. Вторгающаяся в повествование погика «живой жизни» изображается в картинах действительности, оформленных в тексте как вставные новеллы, в которых обнаруживаются повествовательные стратегии физиологического очерка, психологического этюда и нравоучительного рассказа. Предпринятый анализ уточняет представления о жанровой природе и нарративной структуре «статьи» Ипполита - самой большой по объему и значимой для понимания всего романа вставной конструкции.

Ключевые слова: Достоевский, вставные жанры, исповедь, дискурс, нарративные стратегии, новелла, экфрасис

Об авторе: Габдуллина Валентина Ивановна - доктор филологических наук, профессор, профессор кафедры литературы филологического факультета, Алтайский государственный педагогический университет (656031, Российская Федерация, г. Барнаул, ул. Молодежная, 55)

Дата поступления: 24.04.2019

Дата публикации: 09.09.2019

Для цитирования: Габдуллина В. И. Рукопись Ипполита Терентьева в романе Ф. М. Достоевского «Идиот»: жанр и нарративные стратегии // Проблемы исторической поэтики. - 2019. - Т. 17. — № 3. - С. 129-148. DOI: 10.15393/j9.art.2019.5901 
спользование вставных конструкций в повествовательной структуре романов - характерная черта поэтики Ф. М. Достоевского. М. М. Бахтин возводит эту художественную особенность его романов к традициям мениппеи: «Наличие вставных жанров усиливает многостильность и многотонность мениппеи; здесь складывается новое отношение к слову как материалу литературы, характерное для всей диалогической линии развития художественной прозы» [Бахтин, 1972: 327]. С точки зрения В. Н. Захарова, вставляя в свои романы внесюжетные элементы, «которые сами по себе являют жанровое разнообразие, <...> Достоевский явно стремился к жанровому универсализму своих романов» [Захаров, 1997: 145].

Роман Достоевского «Идиот» изобилует вставными жанрами, позволяющими раздвигать рамки сюжетного повествования, обращаться к нравственно-философским, религиозным, бытийным вопросам. Это рассказы князя Мышкина о смертной казни, о судьбе блудницы Мари, видения и сны героев романа, вставные новеллы, анекдоты и др.

Особое место среди множества вставных повествований в романе «Идиот» занимает «Мое необходимое объяснение» Ипполита Терентьева, являющее собой, по определению В. Н. Захарова, «творчество литературного героя» [Захаров, 1997: 145]. Это самая большая по объему и очень важная для понимания всего романа в целом вставная конструкция, которая в тексте произведения называется то «статьей», то «тетрадкой». Чтение рукописи предваряется репликами:

«...я намерен прочесть одну статью <...>

- Статья? В журнал, что ли?» ${ }^{1},-$

очевидно, связанными с одним из черновых проектов романа «Идиот», зафиксированных в подготовительных материалах: «NB) Не кончить ли роман исповедью, напечатанной гласно» (Д30; 9: 220 $)^{2}$.

В записных тетрадях к роману Достоевский неоднократно называет выступление Ипполита «исповедью». О том, что автор склонялся к такому определению прочитанной рукописи, свидетельствует запись, в которой слово «Исповедь» 
вписано вместо зачеркнутого «Рас<сказ>» (Д30; 9: 279). Как справедливо отметил В. Н. Захаров, «у Достоевского была почти религиозная концепция творчества. Как священник на исповеди, писатель был исповедником своих героев, их грехи становились его грехами, увеличивая тяжесть его креста. Свою вину герои и их автор разрешают самим актом творчества: исповедью, покаянием и искуплением своих и чужих грехов» [Захаров, 2013: 161].

Жанровая природа рукописи Ипполита до сих пор вызывает интерес литературоведов. Традиционно «Мое необходимое объяснение» рассматривается как предсмертная исповедь ${ }^{3}$. Уточняется характер исповедального слова у Достоевского, учитывая «двойственную» природу исповеди как феномена культуры: с одной стороны, это «церковный или общинный ритуал самоотчета», с другой - «литературно-публицистический и философский жанр» [Исупов: 3]. Анализ исповедального слова у Достоевского стал предметом целого ряда литературоведческих исследований, авторы которых отмечали как религиозные, так и собственно литературные черты исповедальности в произведениях писателя 4 .

«Исповедь» Ипполита в «Идиоте» рассматривается в одном ряду с «Исповедью Ставрогина» («Бесы») [Исупов], подпольного парадоксалиста («Записки из Подполья») и Аркадия Долгорукова («Подросток») [Криницын, 2001], [Живолупова, 2018], [Честнова]. При этом исповедь «восемнадцатилетнего, истощенного болезнью мальчика» (Д30; 8: 345) принципиально отличается от исповедей подпольного парадоксалиста, Ставрогина или Аркадия Долгорукого, импульс к исповедальному слову которых дает «маркированность» изображаемого события виной героя [Честнова: 8]. Кроме того, важно подчеркнуть, что исповедь Ипполита не только написана, но и прочитана принародно, что, казалось бы, сближает ее с исповедью-покаянием. Однако для Ипполита чтение его рукописи - это не покаяние, а исповедание своей веры, проповедь, продолжение бунта, теоретическое его обоснование, «правда последняя и торжественная» (Д30; 8: 322). Ипполит, досадуя, что «никакого-то воспоминания не сумел оставить! Ни звука, 
ни следа, ни одного дела, не распространил ни одного убеждения!..», - ощущает в себе в то же время дар оратора и проповедника и мечтает «только четверть часа говорить и всех, всех убедить» (Д30; 8: 247-248). Именно поэтому для него важно прочесть свою статью «князю и двум-трем свидетелям» (Д30; 8: 322), на суд которых он выносит свое «последнее убеждение» (Д30; 8: 325).

По сути, рукопись Ипполита - это богоборческий акт, «богоотметное писание» ${ }^{5}$ в котором он утверждает свое право умереть, не дожидаясь срока, определенного ему Богом и природой. Однако, как замечает В. Н. Захаров по поводу исповедальности в произведениях Достоевского, «герой не высказывается весь в словах, а если высказывается, то его слова - ложь» [Захаров, 2013: 158]. По М. М. Бахтину, последнее слово Ипполита - это «исповедь с лазейкой»: «Лазейка создает особый тип фиктивного последнего слова о себе с незакрытым тоном, навязчиво заглядывающего в чужие глаза и требующего от другого искреннего опровержения» [Бахтин, 1972: 402]. Д. Мартинсен считает, что исповедь Ипполита «выдает его подсознательное желание нового начала, а вовсе не конца». Чтение Ипполитом своей рукописи - свидетельство того, что на самом деле он еще не определился, с Богом ли он или с дьяволом. Ипполит хочет верить в Бога и в будущую жизнь, но он «протестует против Бога, подвергшегося унижению» [Мартинсен: 432-433]. По выражению К. В. Мочульского, «Ипполит - не атеист <...>, но и вера его не христианская, а философская» [Мочульский: 399]'

Решившись умереть в Павловске на восходе солнца, Ипполит заявляет:

«Я не признаю судей над собою и знаю, что я теперь вне всякой власти суда» (Д30; 8: 342).

В этом высказывании речь идет не только о людском суде, но и о суде Божьем. Провозглашая право на «саморазрушение», герой Достоевского принимает закон дьявола, о чем свидетельствует ряд деталей в повествовании. 
Представляется не случайным, что «Необходимое объяснение» Ипполит читает после разговора на террасе дачи Лебедева, в котором речь заходит об Апокалипсисе и «нечистом духе»:

«Закон саморазрушения и закон самосохранения одинаково сильны в человечестве! Дьявол одинаково владычествует человечеством до предела времен, еще нам неизвестного» (Д30; 8: 311).

Свое рассуждение о дьяволе Лебедев заканчивает словами: «...ибо нечистый дух есть великий и грозный дух, а не с копытами и с рогами, вами ему изобретенными. Но не в нем теперь дело!..» (Д30; 8: 311).

Обращает на себя внимание реакция Ипполита на эту реплику Лебедева, при упоминании дьявола он ведет себя как одержимый:

«- Почему вы знаете, что не в нем теперь дело? - крикнул вдруг Ипполит и захохотал как будто в припадке» (Д30; 8: 311).

Чтение своей рукописи Ипполит обставляет как некий ритуал, что приводит в замешательство всех собравшихся:

«И вдруг, совершенно неожиданно, он вытащил из своего верхнего бокового кармана большой, канцелярского размера, пакет, запечатанный большою красною печатью. Он положил его на стол пред собой» (Д30; 8: 318).

В контексте предшествующего разговора об Апокалипсисе в сцене подготовки к чтению рукописи и в самом ее тексте обнаруживаются многочисленные аллюзии на Откровение Иоанна Богослова, не указанные в комментариях к роману (Д30; 9: 329-524). Тетрадка, завернутая в пакет, «запечатанный большою красною печатью», отсылает к стихам Апокалипсиса: «И видел я в деснице у Сидящего на престоле книгу, написанную внутри и отвне, запечатанную семью печатями» (Откр. 5:1).

Интрига, предваряющая чтение рукописи Ипполита, также вызывает ассоциации с Откровением Иоанна Богослова: 
«...неужели вы думаете, что я не в состоянии распечатать этот пакет? <..> И видите, как все интересуются; все подошли; все на мою печать смотрят, и ведь не запечатай я статью в пакет, не было бы никакого эффекта! Ха-ха! Вот что она значит, таинственность! <..> Тайна! Тайна!» (Д30; 8: 318-319).
«И видел я Ангела сильного, провозглашающего громким голосом: кто достоин раскрыть сию книгу и снять печати ее? И никто не мог, ни на небе, ни на земле, ни под землею, раскрыть сию книгу, ни посмотреть в нее. И я много плакал о том, что никого не нашлось достойного раскрыть и читать сию книгу, и даже посмотреть в нее. И один из старцев сказал мне: не плачь; вот, лев от колена Иудина, корень Давидов, победил, и может раскрыть сию книгу и снять семь печатей ее» (Откр. 5:2-5); «...когда возгласит седьмой Ангел, когда он вострубит, совершится тайна Божия...»(Откр. 10:7).

Для Ипполита чтение рукописи - его личный Апокалипсис (с греч. - откровение), это он обречен на смерть, ему «вострубил» Ангел смерти, для него «времени больше не будет». Ипполит обращается к Мышкину со словами:

«- <..> А помните, князь, кто провозгласил, что “времени больше не будет"? Это провозглашает огромный и могучий ангел в Апокалипсисе» (Д30; 8: 319).
«И видел я другого Ангела сильного, сходящего с неба, <...> в руке у него была книжка раскрытая. <...> и клялся Живущим во веки веков, <...> что времени уже не будет...» (Откр. 10:1-6).

Время, за которое Ипполит намерен прочитать свою рукопись, также соотносится со временем в Апокалипсисе:

«- Впрочем, не беспокойтесь, я прочту в сорок минут, ну в час...» (Д30; 8: 318).
«И когда Он снял седьмую печать, сделалось безмолвие на небе, как бы на полчаса» (Откр. 8:1).

Парадокс заключается в том, что Ипполит читает свое «богоотметное писание», будучи приговоренным к смерти, что дает ему право ассоциировать себя с Христом — «Агнцем 
как бы закланным» (Откр. 5:6), которому позволено «снять печать» с тайны.

Жанровая природа рукописи Ипполита Терентьева отличается неоднородностью и многослойностью. В ней выделяются вставки, в которых обнаруживаются нарративные стратегии дневника, сновидения, видения, психологического этюда, физиологического очерка, нравоучительного рассказа и идеологического трактата. "Автор неожиданной статьи» (Д30; 8: 321) мучительно ищет форму для своего «Объяснения», сознавая, что «во всякой гениальной или новой человеческой мысли, или просто даже во всякой серьезной человеческой мысли, зарождающейся в чьей-нибудь голове, всегда остается нечто такое, чего никак нельзя передать другим людям, хотя бы вы исписали целые томы...» (Д30; 8: 328).

Начинается «статья» Ипполита с дневниковой записи:

«Вчера утром был у меня князь; между прочим, он уговорил меня переехать на свою дачу» (Д30; 8: 321).

Далее в дневниковую запись вводится описание «хорошенького сна» об «ужасном животном», который Ипполит видел за час до прихода Мышкина. По наблюдению В. В. Савельевой, для онейрических текстов Достоевского характерны «динамизм и сюжетность, фантазийность, интертекстуальность, детализация, пребывание в состоянии осознанного сновидения; субъективность и эмоциональность речевого поведения в процессе вербальной передачи сна» [Савельева: 255]. Важно отметить, что «дурные сны» (Д30; 8: 323) Ипполита передаются самим сновидцем, что отличает их, например, от снов Раскольникова, оформленных как авторский нарратив. В связи с этим в романе «Идиот» не только усиливается психологическая функция сновидения, но и достигается высший уровень эмоционального напряжения за счет непосредственного контакта как со слушателями-персонажами, так и с читателями. Не случайно после эпизода о своем страшном сне, в котором передан весь испытанный им ужас, Ипполит прерывает чтение рукописи, почувствовав его неуместность, так как в нем «слишком много личного» (Д30; 8: 325). 
В соответствии с жанром сновидения этот фрагмент текста содержит символические образы, трактовка которых позволяет понять сокровенные мысли молодого человека, приговоренного к смерти неизлечимой болезнью. Во сне юноша оказывается в большой, светлой комнате, которая воплощает стремление его души к избавлению от темной власти недуга. Но в этом идеальном пространстве появляется «ужасное животное, какое-то чудовище»:

«Оно было вроде скорпиона, но не скорпион, а гаже и гораздо ужаснее, $<\ldots .>$ оно коричневое и скорлупчатое, пресмыкающийся гад, длиной вершка в четыре, у головы толщиной в два пальца, к хвосту постепенно тоньше, так что самый кончик хвоста толщиной не больше десятой доли вершка. <...> два усика на конце хвоста...» (Д30; 8: 323).

Подробное описание вызывающего ужас то ли животного, то ли насекомого, которое сновидец «очень хорошо разглядел» (Д30; 8: 323), во многих деталях напоминает изображение смертоносной «саранчи» в Апокалипсисе: «И из дыма вышла саранча на землю, и дана была ей власть, какую имеют земные скорпионы. <...> и мучение от нее подобно мучению от скорпиона, когда ужалит человека. <...> у ней были хвосты, как у скорпионов, и в хвостах ее были жала; власть же ее была вредить людям пять месяцев (Откр. 9:3, 5, 10).

Рассказывая о своем сне, Ипполит говорит об этом чудовище:

«Я ужасно боялся, что оно меня ужалит; мне сказали, что оно ядовитое, но я больше всего мучился тем, кто его прислал в мою комнату, что хотят мне сделать и в чем тут тайна?» (Д30; 8: 324).

В Апокалипсисе есть объяснение, кто прислал «саранчу», призванную мучить людей, «которые не имеют печати Божией на челах своих»: «Царем над собою она имела ангела бездны; имя ему по-еврейски Аваддон, а по-гречески Аполлион <губитель>» (Откр. 9:11).

Спасение от гадины, которую во сне Ипполита убивает собака, совпадает с приходом Князя, после чего вновь совершается переход от сна к дневниковой записи:

«Тут я проснулся и вошел князь» (Д30; 8: 324). 
«Хорошенький сон» Ипполита перетекает в предшествующий и следующий за ним текст рукописи, что создает ощущение длящегося наяву кошмара. Ипполит понимает, что его рукопись может произвести на слушателей впечатление бреда («жалею, что замучил вас этим бредом (он указал на рукопись)» - Д30; 8: 345).

Важное место в «откровении» Ипполита отводится описанию картины, увиденной в одной из самых мрачных зал дома Рогожина, которую он называет не иначе как «картина Рогожина» (ее настоящее название - «Мертвый Христос» - и имя живописца - Гольбейн - в рукописи не упоминаются). В романе воспроизведены впечатления от этого полотна Льва Мышкина и Ипполита Терентьева; третьим воспринимающим ее субъектом является сам хозяин картины - Парфен Рогожин. При этом все три впечатления совпадают в главном - при взгляде на нее, как говорит князь Мышкин, «вера может пропасть» (Д30; 8: 182).

В описании этой картины автор прибегает к дискурсивной стратегии экфрасиса как особой литературной формы, которая служит для него способом погружения в духовный мир приговоренного к смерти молодого человека, столкнувшегося с законами равнодушной природы 7 . В отличие от беглого замечания-припоминания Мышкина («Я эту картину за границей видел и забыть не могу» - Д30; 8: 181), — в рукописи Ипполита картина описана подробно; читатель вслед за рассказчиком в деталях представляет увиденную им фигуру снятого с креста Иисуса Христа. Но главное в этом фрагменте - не детальное описание полотна, а логика впечатления, приведшая героя к его «последнему убеждению». На Ипполита эта картина произвела «странное беспокойство», он «простоял пред нею минут пять» в состоянии какой-то грезы:

«Природа мерещится при взгляде на эту картину в виде какогото огромного, неумолимого и немого зверя $<. . .>$ ! Картиной этою как будто именно выражается это понятие о темной, наглой и бессмысленно-вечной силе, которой все подчинено, и передается вам невольно» (Д30; 8: 338-339). 
Позднее воспоминание об этой картине погружает Ипполита в сон-бред, в котором он увидел «огромного и отвратительного тарантула» - «то самое темное, глухое и всесильное существо» (Д30; 8: 340). Нельзя не заметить, что видение «неумолимого и немого зверя» ассоциативно связано с образами из апокалиптических снов Ипполита. В бредовом сне Ипполиту кажется, что в его комнате появляется Рогожин, которого он воспринимает если не как самого дьявола, то по меньшей мере как его посланника. Рогожин во сне больного воплощает злой дух, «мрачный и насмешливый, губящий и гибнущий» [Мочульский: 399] $]^{8}$. Ипполит утверждает, что он «решился» высказать прилюдно свое «последнее убеждение» именно после безобразного видения - насмехавшегося над ним Рогожина:

«Нельзя оставаться в жизни, которая принимает такие странные, обижающие меня формы. Это привидение меня унизило» (Д30; 8: 341).

Молчание Рогожина и его усмешка вселяют в Ипполита ужас, подобный тому, который он испытал при взгляде на зверя, несущего смерть. Очевидно, что в этом сне Ипполит прозревает связь Рогожина с инобытием, называя его привидением. Впечатление от картины с изображением мертвого Христа, сон о тарантуле и призрак Рогожина слились в сознании больного в единое целое, что и стало толчком к его «последнему убеждению» - убить себя, от которого Ипполиту «стало легче» (Д30; 8: 341).

Параллельно с онейрическим нарративом, который представлен цепью перетекающих друг в друга снов и видений, граничащих с галлюцинациями и передающих подсознательную мотивацию поступка Ипполита, автор рукописи занят обоснованием «логической цепи выводов», из которой вышло его «последнее убеждение» (Д30; 8: 337). Для него важно «определить за чтением» по впечатлению на слушателей, «правильно ли логическое течение» его мысли (Д30; 8: 322).

Доказывая богоборческую идею о праве на самоубийство, автор рукописи парадоксальным образом вводит тему милосердия, которая представлена в психологическом этюде о «заморозившем» младенца бедном чиновнике Иване Фомиче 
Сурикове и в двух вставных новеллах — о бедном «медике» и о старичке-«генерале».

История о бедняке «из благородных» Сурикове соотносится с двумя следующими за ней вставными новеллами как тезис и антитезис. В данном случае «герой-литератор» воспользовался излюбленным композиционным приемом его создателя - писателя Достоевского, подобным образом строящего опровержение идеи «подпольного» и Раскольникова.

Всегдашняя жалоба Сурикова на жизнь в деталях и по своему духу напоминает исповедь пьяного Мармеладова:

«Беден, нищ и убог, умерла жена, лекарства купить было не на что, а зимой заморозили ребенка; старшая дочь на содержание пошла...» (Д30; 8: 326).

Подобно тому, как Раскольников после знакомства с семейством Мармеладова укрепляется в мысли о своем праве на преступление, Ипполит, приговоренный к смерти неизлечимой болезнью, отрицает милосердие, не испытывая жалости к здоровому человеку, неспособному обеспечить себя:

«Коли он живет, стало быть, всё в его власти! Кто виноват, что он этого не понимает?» (Д30; 8: 327).

Вслед за этим тезисом следует его опровержение, когда «живая жизнь» вносит поправки в умозаключения молодого человека. «Действительность ловила и меня на крючок», - признается Ипполит, предваряя рассказ о своем «добром деле» (Д30; 8: 328). Нарративная стратегия рассказа Ипполита о спасенном им семействе бедного «медика», потерявшего работу, строится по канонам физиологического очерка, в котором повествование минимизировано за счет детального описания быта обедневшей семьи: жалкая комнатушка почти без мебели, одежда, превратившаяся в лохмотья, куски черного хлеба единственное пропитание для четырех человек. История доктора не лишена типического, и Ипполит сам это подчеркивает:

«...дело известное; вы, должно быть, потеряли место и приехали объясняться и опять икать места? <...> Сюда много приезжают из провинций с надеждами, бегают и так вот и живут» (Д30; 8: 332-333) ${ }^{9}$. 
Вместе с тем нельзя не заметить, что «литературное творчество» Ипполита напоминает ранние опыты автора «Бедных людей», «Двойника» и «Господина Прохарчина», в которых начинающий писатель, по его собственному выражению, действует «Анализом, а не Синтезом» (Д30; 28 1,118$)$, поставив в центр изображения душевную жизнь человека, глубина которой не позволяет называть его «маленьким» ${ }^{10}$. В новелле Ипполита о «маленьких людях» план описательно-бытовой переходит в план психологический, в котором рассказчик смещает акценты, несколькими выразительными штрихами давая тонкую характеристику душевных переживаний бедного доктора и его жены. Состояние безысходности, в котором оказалась семья «бедных людей» (не случайно именно это определение своим новым знакомцам дает автор рукописи), заставляет юношу забыть о своих страданиях и ощутить естественную потребность делать добро, которую он считает «природной» человеку:

«Кто посягает на единичную “милостыню”, <..> тот посягает на природу человека и презирает его личное достоинство» (Д30; 8: 335).

Акт милосердия, совершенный Ипполитом, вводит в его «Объяснение» тему добрых дел и единичной «милостыни», которая развивается в следующей вставной новелле о старичке«генерале», начинающейся словами:

«В Москве жил один старик, один “генерал”...» (Д30; 8: 335).

Повествование о «генерале», его бескорыстном милосердии по отношению к «несчастным», как в народе называют преступников, выдержано в жанре предания о святом:

«Он делал свое дело в высшей степени серьезно и набожно <...>. Он давал деньги, присылал необходимые вещи <...>. Он говорил с ними как с братьям <...>. Так поступал он множество лет, до самой смерти...» (Д30; 8: 335).

Эта небольшая новелла так же, как рассказы князя Мышкина о приговоренном к смертной казни, отсылает к опыту, пережитому самим Достоевским, на что в тексте рукописи Ипполита есть указание: 
«Мне рассказывал один бывший в Сибири...» (Д30; 8: 335).

Из этого небольшого рассказа автор «Объяснения» делает вывод о том, что любое, даже малое доброе дело, оставляет след на земле. Мысль эта приходит в противоречие с «последним убеждением» приговоренного к смерти болезнью молодого человека о бессмысленности его собственной жизни. Ему хочется оставить след, заронить «семя», что является одной из побудительных причин появления его рукописи, в которой он проповедует свою идею безбожия. Однако благодаря яркости образов психологических новелл Ипполита его тезис о самоубийстве как праве мыслящей личности опровергается логикой «живой жизни» и ставится под сомнение:

«Единичное добро останется всегда, потому что оно есть потребность личности, живая потребность прямого влияния одной личности на другую» (Д30; 8: 335).

Больной подросток, решившийся на исповедь перед людьми, рассчитывал на их естественную потребность делать добро, отсюда его претензия на их любовь: «Вы меня совсем не любите!» (Д30; 8: 325).

В финале рукописи преобладает ораторская дискурсивная стратегия, вновь сближающая текст рукописи с проповедью, Ипполит настойчиво доказывает свое право на «слово свободное» и на «бунт», видя в нем для себя единственный шанс заявить свою волю:

«Что ж, может быть, я и хочу воспользоваться последнею возможностью дела? Протест иногда не малое дело...» (Д30; 8: 344).

Таким образом, анализ рукописи Ипполита Терентьева «Мое необходимое объяснение» уточняет представление о ее жанровой природе, поэтике и функциях в романе Достоевского «Идиот». Идея о праве человека на самоубийство представлена в рукописи цепью логических умозаключений в нарративе, тяготеющем к философско-публицистическому дискурсу, убежденность и страстная эмоциональная форма которого отсылает к жанру проповеди. Страх смерти и логика подсознания апеллируют к образам Апокалипсиса, проникающим в онейрический нарратив. Вторгающаяся в повествование 
логика «живой жизни» вводится посредством изображения картин действительности, оформленных в тексте как вставные новеллы, в которых обнаруживаются нарративные стратегии физиологического очерка, психологического этюда и нравоучительного рассказа. Сопряжение в тексте различных нарративных стратегий, продиктованное необходимостью обоснования «последнего убеждения» идеологического самоубийцы с позиций логики сознания (тезис) и подсознания и «живой жизни» (антитезис), расширяет жанровые рамки исповеди героя - самой большой по объему и значимой для понимания всего романа Достоевского вставной конструкции.

\section{Примечания}

1 Достоевский Ф. М. Полн. собр. соч.: в 30 т. Л.: Наука, 1973. Т. 8. С. 318,319 . Далее ссылки на это издание приводятся в тексте статьи с использованием сокращения Д30 и указанием тома, книги (нижний индекс), страницы в круглых скобках.

2 В окончательном тексте романа герой заявляет: «Я бы не желал, однако ж, чтоб эта рукопись предана была гласности» (Д30; 8: 342).

3 «Приговоренным к смерти» себя неоднократно называет сам Ипполит. На параллелизм сцен из рассказа о смертной казни князя Мышкина и исповеди Ипполита указал К. В. Мочульский: «Ипполит - молод, правдив, страстен и откровенен... Это - правда приговоренного к смертной казни» [Мочульский: 399]. По замечанию А. Б. Криницына, рассмотревшего рассказ Мышкина о смертной казни и речь Ипполита как бинарные структуры, «именно приговоренность к смерти (или же немедленное самоубийство) должно придать его словам силу» [Криницын: 130].

4 Помимо трудов Л. П. Гроссмана [Гроссман, 1925] и М. М. Бахтина [Бахтин, 1929], в которых была поставлена проблема исповедального слова у Достоевского, следует указать на последовавшие за ними исследования, авторы которых обратились к детальной разработке вопроса: [Соина, 1985], [Криницын, 2001], [Живолупова, 2004, 2008, 2018], [Тяпугина, 2004], [Честнова, 2012], [Луцевич, 2014].

5 В средневековых сюжетах договор человека с дьяволом зачастую скрепляется «рукописанием» или «богоотметным писанием» - богоотступник пишет некий документ, который, «будучи отдан Сатане, $<\ldots>>$ с неизбежностью прикрепляет к нему создателя рукописания, его духовную сущность» [Журавель: 96]. О «богоотметном писании» в структуре романов Достоевского см.: [Габдуллина, 2012].

6 «Какое ему дело до смерти чахоточного подростка? Неужели Мировой Разум станет нарушать свои законы ради какой-то ничтожной мухи? 
Такого Бога Ипполит не может ни понять, ни принять и “оставляет религию”. <...> Ипполит как человек нового поколения смотрит на веру в Христа как на давно пережитый предрассудок» [Мочульский: 399].

7 По замечанию Н. Е. Меднис, «экфрасис ориентирован на выражение того, что в литературе мы назвали бы подтекстом, а в живописи, наверное, затекстом, - это прочтение изображения, не лишенное вчитывания в него дополнительных смыслов, что не только не приводит к деформации экфрасиса как особой литературной формы, но даже укрепляет его, ибо в экфрасисе фиксируется момент встречи двух художников на границе разных видов искусства» [Меднис: 67].

8 Образ Парфена Рогожина в романе дан по контрасту с портретом князя Мышкина с самого начала повествования. В литературоведении закрепилась традиция трактовки характера Рогожина как темного двойника Мышкина, его «демона». См.: [Ахундова: 383-388], [Габдуллина, 2008: 192-193, 197-198].

9 Подобные сюжетные коллизии неоднократно встречаются в романах Достоевского: истории Доброселова и Горшкова («Бедные люди»), Ихменева («Униженные и оскорбленные»), Мармеладова («Преступление и наказание»).

10 Нельзя не согласиться с мыслью В. Н. Захарова: «У Достоевского нет лишних и маленьких людей. Они принципиально невозможны в его мире. Каждый безмерен и значим, у каждого - свое Лицо» [Захаров, 2013: 160].

\section{Список литературы}

1. Ахундова И. Р. «Воплощение хаоса и небытия» (Парфен Рогожин демон смерти или персонификация судьбы) // Роман Достоевского «Идиот»: современное состояние изучения: сб. работ отечественных и зарубежных ученых; под ред. Т. А. Касаткиной. - М.: Наука, 2001. C. $383-388$.

2. Бахтин М. М. Проблемы поэтики Достоевского. - М.: Худож. лит., 1972. $-450 \mathrm{c}$.

3. Бахтин М. М. Проблемы творчества Достоевского. - Л.: Прибой, 1929. $-244 \mathrm{c}$.

4. Габдуллина В. И. «Блудные дети, двести лет не бывшие дома»: евангельская притча в авторском дискурсе Ф. М. Достоевского. - Барнаул: БГПУ, 2008. - 303 c.

5. Габдуллина В. И. Архетипический мотив «договора с дьяволом» в романах Ф. М. Достоевского: «богоотметное писание» // Проблемы исторической поэтики. - Петрозаводск: Изд-во ПетрГУ, 2012. - Вып. 10. C. 133-142 [Электронный pecypc]. - URL: http://poetica.pro/files/ redaktor_pdf/1457954794.pdf (14.01.2019). DOI: 10.15393/j9.art.2012.346

6. Гроссман Л. П. Стилистика Ставрогина. К изучению новой главы «Бесов» // Гроссман Л. П. Поэтика Достоевского. - М.: ГАХН, 1925. C. 144-163. 
7. Живолупова Н. В. Проблема авторской позиции в исповедальном повествовании Достоевского 60-70-х гг. (“Записки из подполья”, “Подросток”) / Российское общество Ф. М. Достоевского; Нижегородский государственный лингвистический университет им. Н. А. Добролюбова. - Н. Новгород: Дятловы горы, 2018. - 229 с.

8. Живолупова Н. В. Исповедь антигероя в архитектонике «Игрока» Достоевского // Вестник ВГУ. Серия: Филология. Журналистика. 2004. - № 1. - С. 13-16.

9. Живолупова Н. В. «Христос и истина» в исповеди антигероя (Достоевский, Чехов, Набоков, Вен. Ерофеев) // Вестник Нижегородского университета им. Н. И. Лобачевского. Серия: Филология. Искусствоведение. - 2008. - № 5. - С. 278-285 [Электронный ресурс]. - URL: http://www.vestnik.unn.ru/ru/nomera?anum=2279 (14.01.2019).

10. Журавель О. Д. Сюжет о договоре человека с дьяволом в древнерусской литературе. - Новосибирск: Книга, 1996. - 234 с.

11. Захаров В. Н. Вставные жанры // Достоевский: эстетика и поэтика: словарь-справочник / сост. Г. К. Щенников. - Челябинск: Металл, 1997. $-272 \mathrm{c}$.

12. Захаров В. Н. Художественная антропология Достоевского // Проблемы исторической поэтики. - Петрозаводск: Изд-во ПетрГУ, 2013. - Вып. 11. - С. 150-164 [Электронный ресурс]. - URL: http:// poetica.pro/files/redaktor_pdf/1431455945.pdf (14.01.2019). DOI: 10.15393/ j9.art.2013.377

13. Исупов К. Г. Исповедь: к определению термина // Метафизика исповеди. Пространство и время исповедального слова. Материалы международной конференции (Санкт-Петербург, 26-27 мая 1997 г.). - СПб.: Изд-во Института Человека РАН (СПб отделение), 1997. - С. 3-5.

14. Криницын А. Б. Исповедь подпольного человека: антропология Ф. М. Достоевского. - М.: Диалог МГУ; МАКС Пресс, 2001. - 371 с.

15. Криницын А. Б. Бинарные структуры в романе Ф. М. Достоевского «Идиот» // Ученые записки Орловского государственного университета. - 2016. — № 2 (71). - С. 129-135.

16. Луцевич Л. Ф. «Если 6 это действительно было покаяние»: исповедь Николая Ставрогина // Вестник Башкирского университета. - 2014. Т. 19. 一 № 4. - С. 1339-1344.

17. Мартинсен Д. Повествования о самообособлении: литературные самоубийства в творчестве Достоевского // Роман Ф. М. Достоевского «Идиот»: современное состояние изучения. Сборник работ отечественных и зарубежных ученых / под ред. Т. А. Касаткиной. - М.: Наследие, 2001. - C. 425-435.

18. Меднис Н. Е. «Религиозный экфрасис» в русской литературе // Критика и семиотика. - Новосибирск, 2006. - Вып. 10. - С. 58-67.

19. Мочульский К. В. Гоголь. Соловьев. Достоевский. - М.: Республика, 1995. - 607 c. 
20. Савельева В. В. Художественная гипнология и онейропоэтика русских писателей. - Алматы: Жазушы, 2013. - 520 с.

21. Соина О. С. Исповедь как наказание в романе «Братья Карамазовы» // Достоевский. Материалы и исследования. - Л.: Наука, 1985. - Вып. 6. — С. $129-136$.

22. Тяпугина Н. Ю. Исповедь и проповедь Достоевского. - Саратов: СГАП, 2004. - 350 c.

23. Честнова Н. Ю. Исповедальность как принцип становления поэтики художественной прозы Ф. М. Достоевского (на материале повести «Записки из подполья» и романа «Подросток»): автореф. дис. ... канд. филол. наук. - Владимир, 2012. - 26 с.

Valentina I. Gabdullina

(Barnaul, Russian Federation)

vigv@mail.ru

\title{
The Manuscript of Ippolit Terentyev in the Novel "The Idiot" by F. M. Dostoevsky: Genre and Narrative Strategies
}

\begin{abstract}
The manuscript of Ippolit Terentyev "My Indispensable Explication", referred to as an "article" or a "notebook" in Dostoevsky's novel, is traditionally seen as a confession in literary studies. Meanwhile, the genre and narrative structure of Ippolit's manuscript is not homogeneous, but multilayer. The conjugacy of various discursive strategies of justifications of the "last conviction" of the ideological self-destroyer in the text, from the viewpoint of the logic of the conscious (thesis) and subconscious and "true live" (antithesis), enlarges genre limits of the confessional word. The idea of the human right to commit suicide appears in the manuscript in the form of the number of conclusions in the narration that rather resembles a philosophical and publicistic discourse, the convincing and fervent emotional manner of which refers us to the genre of a preaching text. The logic of the subconscious of a dying young man appeals to the images of Apocalypses and non-existence penetrating into the night fantasy narration. The fear of death and the loss of faith are embodied in a discursive strategy of ecphrasis. The logic of the "true life" penetrating into the narration manifests itself in the scenes of reality, that appear in the text as the cut-in novelettes containing narrative strategies of a physiological essay, psychological sketch and moralizing story. The conducted analysis specifies the ideas about genre and narrative structure of the "article" of Ippolit, the largest and most important one for comprehension of the whole novel of a cutin construction.
\end{abstract}

Keywords: Dostoevsky, inserted genres, confession, discourse, narrative strategies, novelette, ecphrasis 
About the author: Gabdullina Valentina I. - Doctor of Philology, Professor, Professor of the Department of Russian and World Literature of Faculty of Philology, The Altai State Pedagogical University (ul. Molodezhnaya 55, Barnaul, 656031, Russian Federation)

Received: April 24, 2019

Date of publication: September 9, 2019

For citation: Gabdullina V. I. The Manuscript of Ippolit Terentyev in the Novel “The Idiot" by F. M. Dostoevsky: Genre and Narrative Strategies. In: Problemy istoricheskoy poetiki [The Problems of Historical Poetics], 2019, vol. 17, no. 3, pp. 129-148. DOI: 10.15393/j9.art.2019.5901 (In Russ.)

\section{References}

1. Akhundova I. R. "The Embodiment of Chaos and Nothingness" (Parfen Rogozhin - the Demon of Death or the Personification of Fate). In: Roman Dostoevskogo "Idiot»: sovremennoe sostoyanie izucheniya: sbornik rabot otechestvennykh i zarubezhnykh uchenykh [Dostoevsky's Novel "The Idiot": the Current State of Study: a Collection of Works by Home and Foreign Scientists]. Moscow, Nauka Publ., 2001, pp. 383-388. (In Russ.)

2. Bakhtin M. M. Problemy poetiki Dostoevskogo [The Problems of Dostoevsky's Poetics]. Moscow, Khudozhestvennaya literatura Publ., 1972. 450 p. (In Russ.)

3. Bakhtin M. M. Problemy tvorchestva Dostoevskogo [The Problems of Dostoevsky's Works]. Leningrad, Priboy Publ., 1929. 244 p. (In Russ.)

4. Gabdullina V. I. "Bludnye deti, dvesti let ne byvshie doma»: evangel'skaya pritcha $v$ avtorskom diskurse F. M. Dostoevskogo ["Prodigal Children, Absent from Home for Two Hundred Years": a Evangelical Parable in the Author's Discourse of F. M. Dostoevsky]. Barnaul, Barnaul State Pedagogical University Publ., 2008. 303 p. (In Russ.)

5. Gabdullina V. I. Archetypical Motif of a Pact with the Devil in the Novels by Dostoevsky: "God-forsaking Scripture". In: Problemy istoricheskoy poetiki [The Problems of Historical Poetics]. Petrozavodsk, PetrSU Publ., 2012, issue 10, pp. 133-142. Available at: http://poetica.pro/files/redaktor_ pdf/1457954794.pdf (accessed on January 14, 2019). DOI: 10.15393/j9. art.2012.346 (In Russ.)

6. Grossman L. P. The Stylistics by Stavrogin. On the Study of a New Chapter of "Demons". In: Grossman L. P. Poetika Dostoevskogo [Grossman L. P. Dostoevsky's Poetics]. Moscow, The State Academy of Arts Publ., 1925, pp. 144-163. (In Russ.)

7. Zhivolupova N. V. Problema avtorskoy pozitsii v ispovedal'nom povestvovanii Dostoevskogo 60-70-kh gg. ("Zapiski iz podpol'ya", "Podrostok"): monografiya [The Problem of the Author's Position in the Confessional Narration of Dostoevsky in the 1860s-1870s ("Notes from Underground", "The Raw Youth"): Monograph]. Nizhny Novgorod, Dyatlovy gory Publ., 2018. 229 p. (In Russ.)

8. Zhivolupova N. V. A Confession of an Antihero in the Architectonics of "The Gambler" by Dostoevsky. In: Vestnik Voronezhskogo gosudarstvennogo 
universiteta. Seriya: Filologiya. Zhurnalistika [Proceedings of Voronezh State University. Series: Philology. Journalism], 2004, no. 1, pp. 13-16. (In Russ.)

9. Zhivolupova N. V. "Christ and the Truth» in the Subgenre of Antihero's Confession (Dostoevsky, Chekhov, Nabokov, Ven. Erofeev). In: Vestnik Nizhegorodskogo universiteta im. N. I. Lobachevskogo. Seriya: Filologiya. Iskusstvovedenie [Vestnik of Lobachevsky University of Nizhni Novgorod. Series: Philology. Art History], 2008, no. 5, pp. 278-285. Available at: http:// www.vestnik.unn.ru/ru/nomera?anum=2279 (accessed on January 14, 2019). (In Russ.)

10. Zhuravel' O. D. Syuzhet o dogovore cheloveka s d'yavolom $v$ drevnerusskoy literature [A Plot of the Deal Between a Man and the Devil in Ancient Literature]. Novosibirsk, Kniga Publ., 1996. 234 p. (In Russ.)

11. Zakharov V. N. Inserted Genres. In: Dostoevskiy: estetika i poetika: slovar'spravochnik [Dostoevsky: Aesthetics and Poetics: Dictionary and Reference Book]. Chelyabinsk, Metall Publ., 1997. 272 p. (In Russ.)

12.Zakharov V. N. Dostoevsky's Poetic Anthropology. In: Problemy istoricheskoy poetiki [The Problems of Historical Poetics]. Petrozavodsk, PetrSU Publ., 2013, issue 11, pp. 150-164. Available at: http://poetica.pro/files/redaktor_ pdf/1431455945.pdf (accessed on January 14, 2019). DOI: 10.15393/j9. art.2013.377 (In Russ.)

13. Isupov K. G. Confession: on the Definition of the Term. In: Metafizika ispovedi. Prostranstvo i vremya ispovedal'nogo slova. Materialy mezhdunarodnoy konferentsii (Sankt-Peterburg, 26-27 maya 1997 goda) [The Metaphysics of Confession. Space and Time of the Confessional Word. Proceedings of the International Conference (St. Petersburg, 26-27 May 1997)]. St. Petersburg, Human Institute of The Russian Academy of Sciences Publ., 1997, pp. 3-5. (In Russ.)

14. Krinitsyn A. B. Ispoved' podpol'nogo cheloveka: antropologiya F. M. Dostoevskogo [A Confession of an Underground Man: F. M. Dostoevsky's Anthropology]. Moscow, Dialog MGU Publ., MAKS Press Publ., 2001. 371 p. (In Russ.)

15. Krinitsyn A. B. Binary Structures in F. M. Dostoevsky's Novel "The Idiot”. In: Uchenye zapiski Orlovskogo gosudarstvennogo universiteta [Scientific Notes of Orel State University], 2016, no. 2 (71), pp. 129-135. (In Russ.)

16. Lutsevich L. F. "If it Really Was Repentance": Stavrogin's Confession. In: Vestnik Bashkirskogo universiteta [Bulletin of Bashkir University], 2014, vol. 19, no. 4, pp. 1339-1344. (In Russ.)

17. Martinsen D. The Narration About Self-Isolation: Literary Suicide in the Works of Dostoevsky. In: Roman F. M. Dostoevskogo «Idiot»: sovremennoe sostoyanie izucheniya. Sbornik rabot otechestvennykh i zarubezhnykh uchenykh [The Novel by F. M. Dostoevsky "The Idiot": the Current State of Study. A Collection of Works of Home and Foreign Scientists]. Moscow, Nasledie Publ., 2001, pp. 425-435. (In Russ.)

18. Mednis N. E. "Religious Ecphrasis" in Russian Literature. In: Kritika i semiotika [Criticism and Semiotics]. Novosibirsk, 2006, issue 10, pp. 58-67. (In Russ.) 
19. Mochul'skiy K. V. Gogol, Solovyov, Dostoevsky. Moscow, Respublika Publ., 1995.607 p. (In Russ.)

20.Savel'eva V. V. Khudozhestvennaya gipnologiya i oneyropoetika russkikh pisateley [The Art Hypnology and Onyropoetics of Russian Writers]. Almaty, Zhazushy Publ., 2013. 520 p. (In Russ.)

21. Soina O. S. Confession as Punishment in the Novel "The Brothers Karamazov". In: Dostoevskiy. Materialy i issledovaniya [Dostoevsky. Materials and Researches]. Leningrad, Nauka Publ., 1985, issue 6, pp. 129-136. (In Russ.)

22. Tyapugina N. Yu. Ispoved' i propoved' Dostoevskogo [The Confession and Preaching of Dostoevsky]. Saratov, Saratov State Academy of Law Publ., 2004. 350 p. (In Russ.)

23. Chestnova N. Yu. Ispovedal'nost' kak printsip stanovleniya poetiki khudozhestvennoy prozy F. M. Dostoevskogo (na materiale povesti «Zapiski iz podpol'ya» i romana "Podrostok»): avtoref. dis. ... kand. filol. nauk [Confessions as a Principle of Formation of the Poetics of Dostoevsky's Prose (Based on the Material of the Novels "Notes from Underground" and "The Raw Youth"). PhD. philol. sci. diss. abstract]. Vladimir, 2012. 26 p. (In Russ.) 